\title{
Thresholds for tracing ships' ballast water: an Australian case study
}

\author{
Martina A. Doblin ${ }^{1, *}$, Kathleen R. Murphy ${ }^{2,3}$, Gregory M. Ruiz ${ }^{2}$ \\ ${ }^{1}$ Plant Functional Biology and Climate Change Cluster, Faculty of Science, University of Technology Sydney, \\ PO Box 123 Broadway, New South Wales 2007, Australia \\ ${ }^{2}$ Smithsonian Environmental Research Center, 647 Contees Wharf Road, Edgewater, Maryland 21037, USA \\ ${ }^{3}$ UNSW Water Research Centre, School of Civil and Environmental Engineering, The University of New South Wales, \\ Sydney, New South Wales 2052, Australia
}

\begin{abstract}
To limit the spread of non-indigenous marine species, ships can be legally required to conduct ballast water exchange (BWE) prior to discharging ballast water. It has been proposed to verify BWE by measuring concentrations of coastal tracers in ballast tanks, which should track their removal. Using 3 Australian ports as case studies (Port Botany, Port Curtis and Port Phillip Bay), each representing a different BWE verification difficulty level, the spatial and temporal variability of chromophoric dissolved organic matter (CDOM) and 3 trace elements (manganese [Mn], barium [Ba] and phosphorus [P]), were measured to assess their utility as tracers of coastal (unexchanged) ballast water. CDOM fluorescence at $\lambda_{\text {ex }} / \lambda_{\text {em }}=320 / 414 \mathrm{~nm}\left(\mathrm{C} 2^{*}\right)$ and 370/494 nm (C3*) and Mn concentrations were significantly higher in ports than in the adjacent Tasman Sea, except near port entrances and at a few sites in Port Botany. Ba concentrations demonstrated the least power to discriminate coastal sources, but P easily discriminated water from mesotrophic Port Phillip Bay. In general, tracers showed greater variation between and within ports, rather than between seasons. Conservative BWE thresholds were calculated to be 1.6 quinine sulphate equivalents for $\mathrm{C} 2{ }^{*}, 0.9$ quinine sulphate equivalents for $\mathrm{C}^{*}, 1.4 \mu \mathrm{g} \mathrm{l}^{-1}$ for $\mathrm{Mn}$ and $6.9 \mu \mathrm{g}^{-1}$ for Ba. Overall, these thresholds would allow water sourced from eastern Australian ports to be identified as coastal at $92 \%, 69 \%$ and $74 \%$ of sites examined using $\mathrm{C}^{*}$, $\mathrm{Mn}$ and $\mathrm{Ba}$, respectively, requiring $71 \pm 26 \%, 54 \pm 40 \%$ and $59 \pm 38 \%$ replacement with mid-ocean water to be within ocean baseline concentration ranges.
\end{abstract}

KEY WORDS: Ballast water $\cdot \mathrm{CDOM} \cdot$ Trace elements $\cdot$ Biological invasions $\cdot$ Ballast management Resale or republication not permitted without written consent of the publisher

\section{INTRODUCTION}

Propagule supply is a key process in the dynamics of marine assemblages, providing the pool of potential new recruits (Underwood \& Keough 2001). Densitydependent processes such as reproduction also have profound impacts on population establishment through the Allee-effect, where fitness is reduced at low conspecific densities (Taylor \& Hastings 2005). Indeed, the number of arrivals to new habitats has been consistently correlated with non-indigenous species establishment (Hayes \& Barry 2008), indicating that 'propagule pressure' (Williamson 1996) is a fundamental driver of anthropogenically-mediated biological invasions (Verling et al. 2005).
Not surprisingly, decreasing propagule pressure to aquatic environments underpins local, national and international policies to manage risk of invasive species (EPA Victoria 2004, IMO 2004, MAF 2005, 2007). For marine systems, ships' ballast water is unarguably the largest anthropogenic vector for planktonic lifestages and microorganisms (Drake et al. 2007), with billions of tonnes of water being delivered to ports annually. The International Maritime Organisation's (IMO) International Convention for the Control and Management of Ships Ballast Water and Sediments D2 regulation (IMO 2004) aims to reduce the concentration of organisms in ballast water by several orders of magnitude. While significant research and development is underway to achieve this through treatment 
technologies, ballast water exchange (BWE) at sea is currently the major practice by which ships reduce the delivery of propagules to foreign and domestic ports, and current regulations require that the prescribed management measure-typically $95 \%$ volumetric replacement of coastal with oceanic seawater (IMO 2004, US Coast Guard 2004, CSLC 2006) — has been undertaken. Despite the phasing out of BWE by 2016, it will be the means of ballast treatment for at least another $6 \mathrm{yr}$, and is likely to be used as a backup by ships that cannot implement their adopted technology for one reason or another, such as process failure.

Studies in the North Atlantic and Pacific Oceans have identified several chemical tracers that can track the performance of BWE in removing port water, including salinity, chromophoric dissolved organic matter (CDOM), manganese $(\mathrm{Mn})$, barium $(\mathrm{Ba})$ and phosphorus (P; Murphy et al. 2004, 2006, 2008a, Hunt et al. 2007). Concentrations of all tracers other than salinity are typically elevated in ports relative to the mid-ocean where BWE takes place, due to their closer proximity to terrestrial sources and human activities. This is particularly the case when ports are positioned at river mouths, where large quantities of terrestrial materials are exported to the ocean (e.g. Macquarie Harbour, Tasmania, Australia; Carpenter et al. 1991).

Little is known about the spatial or temporal variability of potential ballast water tracers in southern Pacific waters (cf. Hunt et al. 2007, Murphy et al. 2009a). Australian ports are expected to be amongst the most challenging ports globally for BWE verification due to a combination of lowest percentage of rainfall as runoff (average of $12 \%$ compared to $33 \%$ for North America), highest spatial and temporal variability in rainfall and runoff, low relief and nutrient-poor soils (Arthington \& Pusey 2003, Davis \& Koop 2006), resulting in potentially low and variable terrestrial signals. Of particular concern is the number of Australian ports containing large populations of invasive species (CRIMP 1996, Aquenal 2001, Hewitt et al. 2004). These populations are at risk of secondary dispersal via ballast water, both domestically and to foreign ports. For BWE verification to be used as a management tool, it is therefore critical to evaluate the effectiveness of proposed tracers for Australian ports.

A difficult and potentially controversial aspect of verifying BWE using tracer methods is deciding upon appropriate thresholds for discriminating between exchanged and unexchanged ballast water. Tentative BWE thresholds have been proposed for CDOM (Murphy et al. 2006) and for Ba and Mn (Murphy et al. 2008a), based upon tracers measured in the ballast tanks of ships operating in the North Pacific and Atlantic Oceans. A limitation of that approach was that the efficiency of ballast water exchange (and there- fore, the proportion of port water retained in 'exchanged' ballast tanks) was not accurately known for most ships, and this uncertainty was propagated into the calculation of BWE thresholds. This limitation may be overcome by calculating the mixing between endpoints with known chemical quantities, i.e. the original port water and the ambient ocean where ballast water is exchanged. Assuming replacement of port with oceanic seawater during BWE, tracer concentrations in ballast tanks should diminish linearly with increasing exchange efficiency (Fig. 1). When no coastal ballast water remains, tracer concentrations in ballast tanks should be at oceanic levels. Current regulations specify a minimum of $95 \%$ volumetric replacement of port water during $\mathrm{BWE}$; thus the BWE threshold can be calculated as the concentration of tracer which would be achieved if a ballast tank were to contain $95 \%$ port water and $5 \%$ oceanic seawater.

Like elsewhere, Australian ports differ in their configuration (e.g. port volume and flushing rate), freshwater (and other) inflows and seasonal runoff patterns, providing a range of potential source waters for ships' ballast (Table 1). As a first order estimate, open ports with oceanic salinities (>30 psu) are classed as 'difficult' test cases, since low river inputs correlate with low concentrations of CDOM and other terrestrial

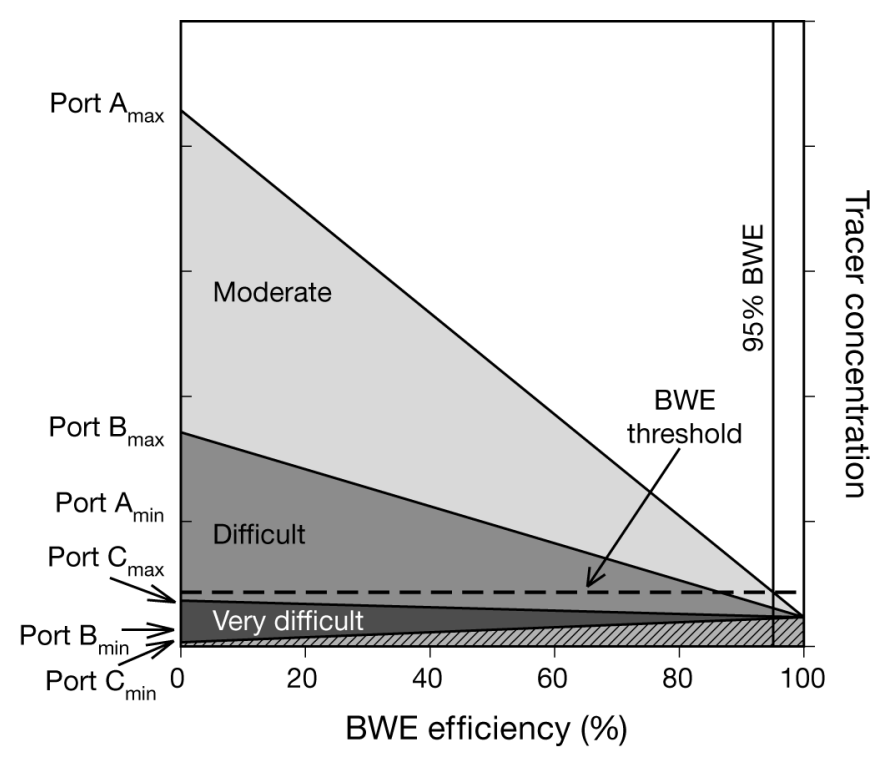

Fig. 1. Theoretical tracer concentration ranges in 3 ports and how their concentration would change with volumetric ballast water exchange (BWE). The potential BWE threshold (dashed horizontal line) is the tracer concentration which would be achieved if port water containing the maximum tracer concentration were replaced with ocean water at $95 \%$ BWE efficiency. The hatched grey band at the bottom represents the range of tracer concentration in the ocean (average $\pm 2 \mathrm{SD}$ ). In this scheme, Port A contains ballast water that would have a Moderate BWE verification difficulty, whereas water sourced from Port $\mathrm{B}$ and $\mathrm{C}$ would have Difficult or Very Difficult status, respectively 
markers (Ferrari \& Dowell 1998, Blough \& Del Vecchio 2002, J. Boehme et al. unpublished). It is apparent that the majority of Australian ports are likely to represent moderate to high-difficulty cases for BWE verification (Table 1). Using 3 locations as test cases, we assessed the spatial and temporal variability of chemical tracers in ports representative of different estimated BWE verification difficulty levels: (1) Moderate (Port Phillip Bay), (2) Difficult (Port Curtis) and (3) Very Difficult (Port Botany). The objectives were to assess whether chemical tracer concentrations in these representative ports consistently differ from those in the adjacent open ocean, to propose BWE thresholds appropriate for these ports, and to evaluate their effectiveness given within- and between-port variability and differing BWE efficiencies, on verifying BWE on ships carrying ballast from Australian ports.

\section{MATERIALS AND METHODS}

Port assessment. Given that it would take significant resources to sample all 73 ports within Australia, they were first evaluated for their importance as ballasting locations. An earlier analysis by Hayes et al. (2005) using Lloyds Maritime Intelligence Unit data together with an environmental matching analysis, revealed the top 20 locations in Australia where pest incursions are most likely, based on the translocation of ships' ballast water and known port infestation status (Table 1; Hayes et al. 2005). While these locations are those importing (rather than exporting) the largest volumes of ballast water, this list has been used as a way of prioritising the existing ports in Australia to evaluate how easy it would be to verify them as coastal ballast sources. From this subset, ports were then assessed for the presence of nearby freshwater inputs (including whether they were located within an estuary, the estuary width and area), their openness to the ocean (i.e. distance from shipping berths to the ocean) and regional climate (e.g. average annual precipitation, rainfall seasonality). These parameters were combined to assess the overall ease of using salinity and other tracers as a BWE verification measure, and ports were ranked accordingly (with rank 1 being easiest to verify). Where possible, the ranking was cross-checked with in situ salinity data from published and other credible sources. Although Port Phillip Bay and Port Curtis were ranked 6th and 7th, they were given a different BWE verification status (Moderate and Difficult, respectively) because of Port Phillip Bay's relatively long residence time (Harris et al. 1996), which would allow terrestrial markers to accumulate. Port Botany with its close proximity to the coast and relative openness to the ocean was deemed Very Difficult.
Port surveys. Port Botany, Port Curtis and Port Phillip Bay (approximate latitudes $34^{\circ} \mathrm{S}, 23^{\circ} \mathrm{S}$ and $38^{\circ} \mathrm{S}$ (Fig. 2), representing Very Difficult, Difficult and Moderate BWE verification status, were sampled for their spatial and temporal variability of tracers (Murphy et al. 2009b). Seasonal variability was assessed for Port Curtis and Port Phillip Bay, as these ports have distinct precipitation patterns (summer monsoon versus winter-dominated rainfall, respectively). All surveys were deliberately conducted during periods of low rainfall so that port water would be most challenging to identify as coastal. Sampling of Port Botany was conducted in autumn on 18 to 19 April 2007 (Port Botany fall). Water samples were collected at 24 sites throughout Botany Bay (Fig. 2). The first field survey of Port Phillip Bay was conducted from 24 to 26 April 2007 (Port Phillip fall). Samples were collected at 24 sites encompassing the Port of Geelong (6 sites), the Port of Melbourne (9 sites) and the wider Bay region (9 sites; Fig. 2). End-member samples were also collected from the Yarra River at Studley Park boathouse (above Dights Falls, the uppermost extent of the tidal excursion), which is the major source of fresh water to the Port of Melbourne (Harris et al. 1996). The second survey of Port Phillip Bay (Port Phillip spring) took place on 25 to 26 October 2007. Sampling locations during the second survey were as close as possible to the sites visited in the first survey. Two surveys were conducted in Port Curtis near Gladstone. Approximately half of the sites were chosen to coincide with sites previously surveyed by the former Centre for Research on Introduced Marine Pests (CRIMP) and the University of Central Queensland (UCQ) during the baseline surveys of introduced marine species in Australian ports (Lewis et al. 2001). The remainder were selected principally to provide coverage of the Calliope River and point sources to the port. The first survey was conducted on 21 to 22 August 2007 (Port Curtis winter; Fig. 2). A second survey (Port Curtis fall) was conducted on 2 to 4 April 2008 (Fig. 2).

During each port survey, water was collected for analysis of CDOM and trace metals (molybdenum [Mo], Ba, Mn, P) at each site, encompassing a marine end-member collected near the port entrance, sites near features such as shipping terminals, active berths and shipping channels, and an upstream site to represent a freshwater source.

Sample collection. Water samples for laboratory analysis of trace elements and CDOM (n = 3 each) were collected at $5 \mathrm{~m}$ depth (or $1 \mathrm{~m}$ off the bottom at shallow sites) using a peristaltic pump (Cole Parmer 7533-60 12 V DC) fitted with rigid Teflon tubing and flexible Masterflex tubing and connected to a highcapacity inline $0.45 \mu \mathrm{m}$ capsule filter (GE Memtrex MP). Sampling depth was at $5 \mathrm{~m}$ since this is a typical 


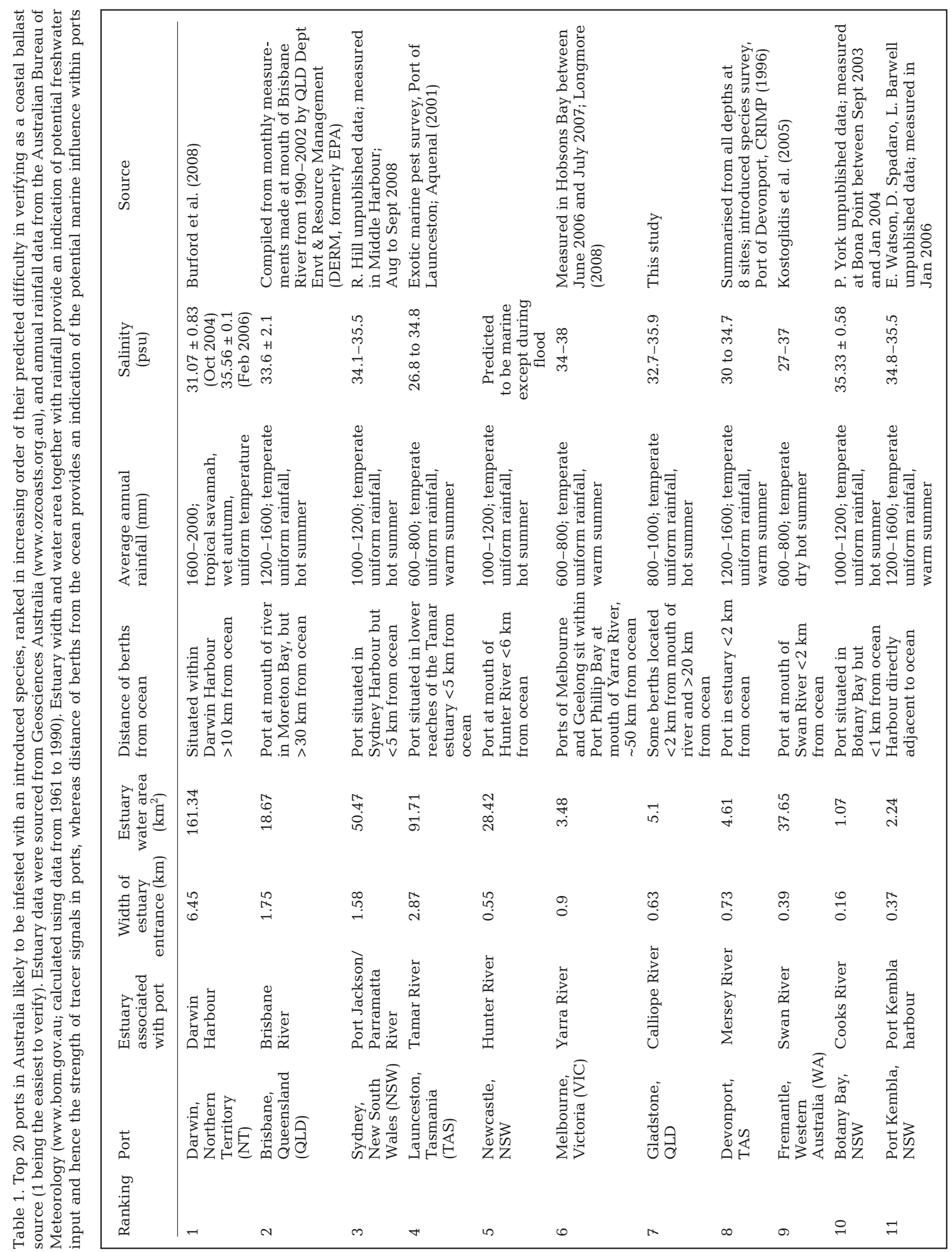




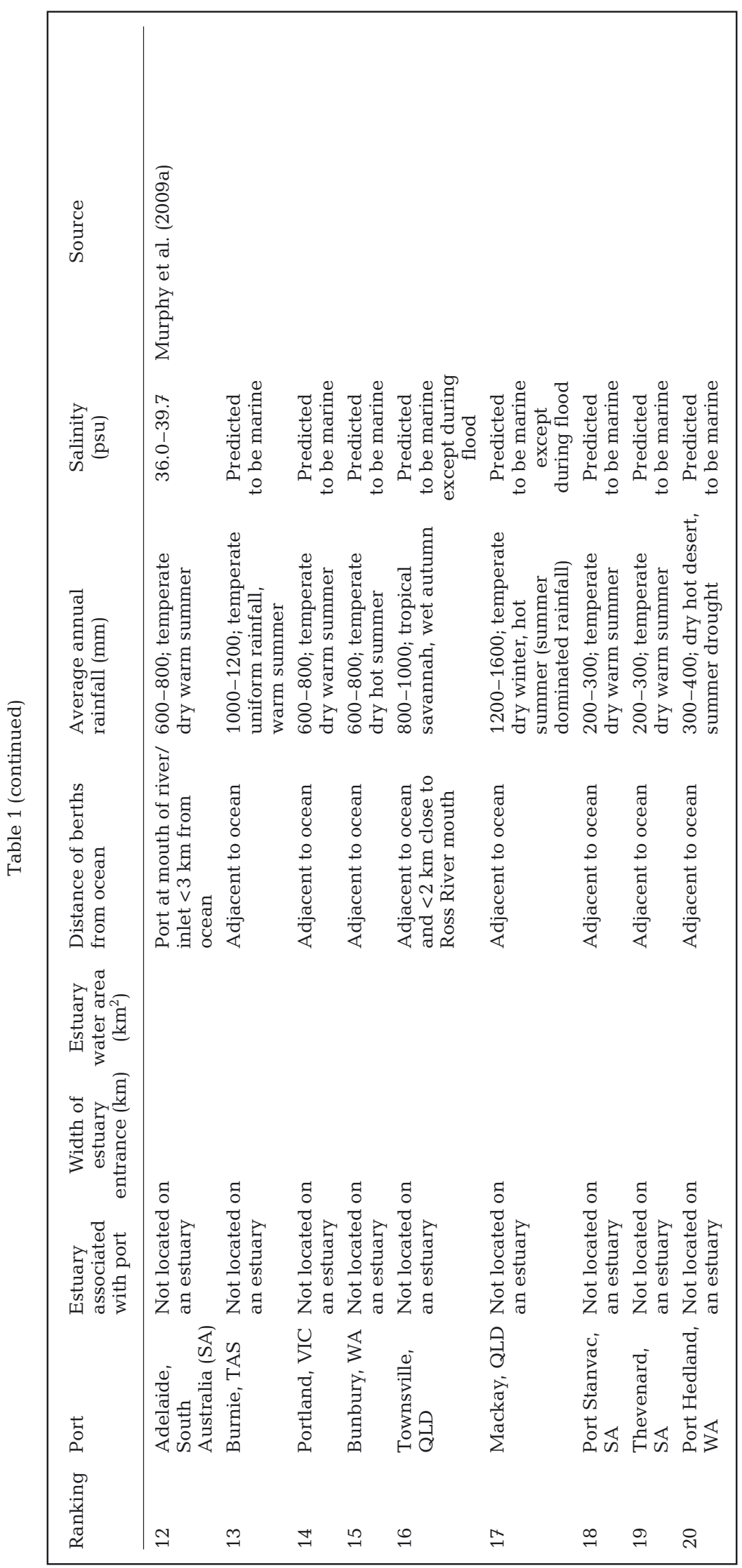

location of ships' ballast water intake vents. The apparatus was flushed with at least 31 of water prior to sampling, and filters were changed 3 to 5 times during each survey depending on turbidity levels in the port. All tubing and filters were acid-washed before use. Additional air samples to assess trace element baselines $(n=3)$ were also collected at locations where aerosol input was thought to be significant, such as the Sydney Airport runway approach in Botany Bay (Fig. 2). Filtered water was collected in acid-cleaned $50 \mathrm{ml}$ plastic centrifuge tubes for trace element analyses, or ashed amber glass bottles for CDOM analyses. Following collection, samples were stored on the boat in a cooler, then refrigerated and ultimately frozen at $-20^{\circ} \mathrm{C}$ before being shipped to the US for analysis.

Physico-chemical characteristics. Physico-chemical profiles were measured in situ every 1 to $5 \mathrm{~m}$ depth (deep sites) or to $0.5 \mathrm{~m}$ off the bottom at shallow sites. Salinity, conductivity, temperature and dissolved oxygen were measured using 1 or both of a YSI-85 and YSI 650MDS datasonde equipped with a 65 probe. Instruments were calibrated with a NIST-traceable seawater conductivity standard (YSI 3169, $50 \mathrm{mS}$ $\mathrm{cm}^{-1}$ ) or with a freshly-made solution of $0.5 \mathrm{M} \mathrm{KCl}$ (conductivity $=58.640 \mathrm{mS}$ $\mathrm{cm}^{-1}$ ) prior to each cruise. During the Port Botany and winter Port Curtis surveys, the precision of field measurements of salinity was determined to be approximately \pm 2 psu (6\%) at 35 psu, which was lower than desired. Consequently in later surveys, both instruments were recalibrated just before use, and salinities measured in the field were cross-checked against laboratory measurements conducted on samples sent to the Smithsonian Environmental Research Laboratory (SERC). The precision of salinity measurements in all other surveys was determined to be approximately $\pm 0.5 \mathrm{psu}(1.5 \%)$ at $35 \mathrm{psu}$.

Sample analysis. Samples were shipped to the US for analyses to be consistent with previous studies (Murphy et al. 2004, 2009a). Trace element samples were analysed at Rutgers Inor- 

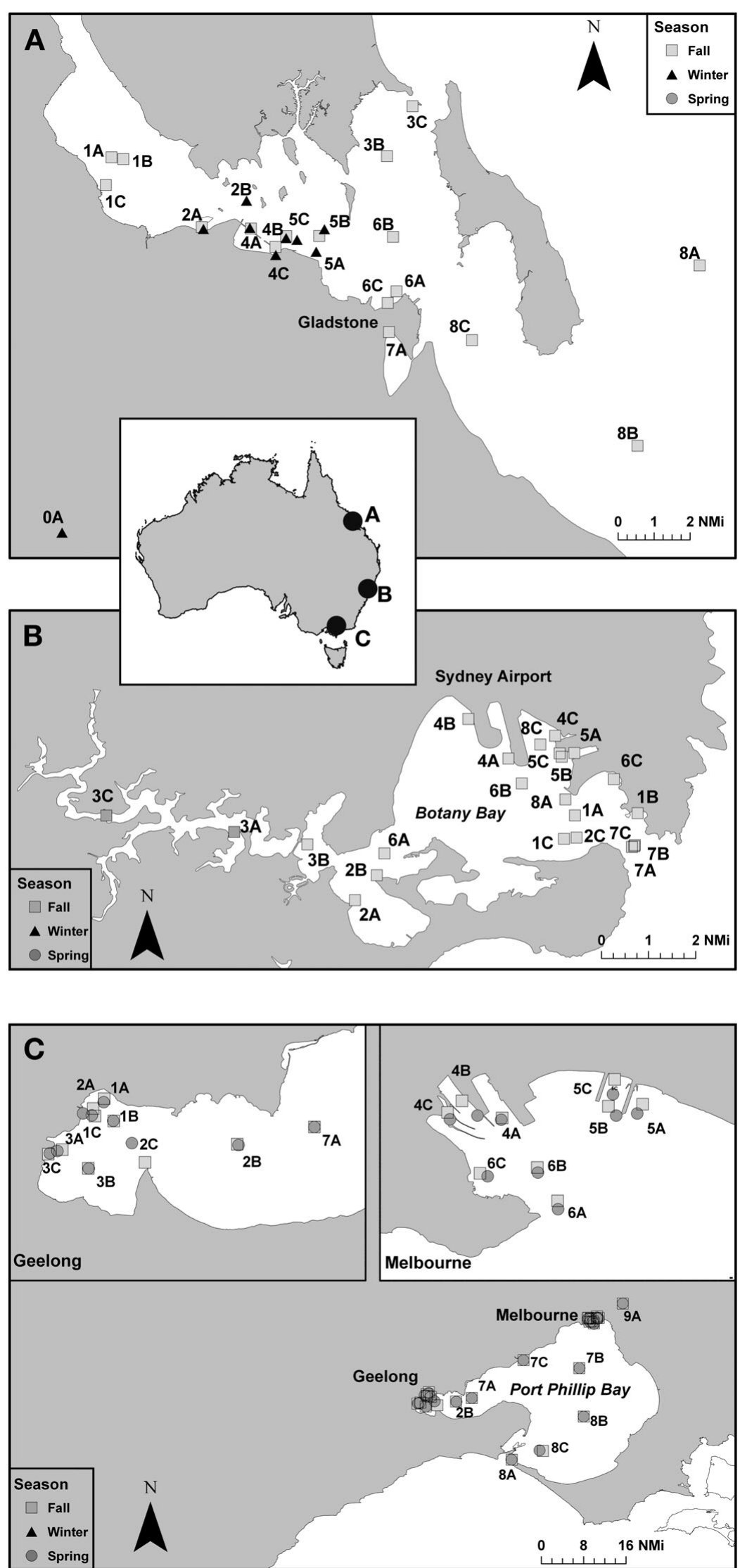

ganic Analytical Laboratory, Institute of Marine and Coastal Sciences, Rutgers, the State University of New Jersey. Samples were analysed on a sector field inductively coupled plasma mass spectrometer (ICP-MS) with high-resolution capability (ELEMENT, Finnigan MAT). Total dissolved concentrations of 4 trace elements $(\mathrm{Ba}, \mathrm{Mn}, \mathrm{Mo}, \mathrm{P})$ were determined according to published methods (Field et al. 2007). All 3 trace element replicates were analysed from each site, except during the second survey of Port Curtis, for which 2 replicates per site were analysed.

CDOM analysis was performed by excitation-emission matrix spectroscopy (EEMS) at SERC, using a JY Horiba Spex Fluorolog-3 (Edison). Samples were analysed in a $1 \mathrm{~cm}$ quartz cell maintained at $20^{\circ} \mathrm{C}$ with a temperaturecontrolled cell holder and processed in ratio mode with a $0.5 \mathrm{~s}$ integration time and a $5 \mathrm{~nm}$ bandwidth for both excitation and emission. The experimental wavelength range was 220 to $455 \mathrm{~nm}$ in $5 \mathrm{~nm}$ intervals on excitation and 290 to $700 \mathrm{~nm}$ in $4 \mathrm{~nm}$ intervals on emission. Fluorescence excitation-emission matrices (EEMs) were corrected for instrument and lamp variability and normalised to parts per billion quinine sulphate equivalent units (QSE) as previously described (Coble et al. 1993, method 1) using an in-house program written for Matlab (Ver. 7). Although full EEMs were collected, following Murphy et al. (2006), only the excitation/emission ratios of $\mathrm{C} 2{ }^{*}=320 / 414 \mathrm{~nm}$ and $\mathrm{C} 3{ }^{*}=$ $320 / 494 \mathrm{~nm}$ are presented. These wavelengths are used as indicators for 2 mathematically independent humiclike fluorescence components present in ships' ballast (components C2 and C3 in Murphy et al. 2006), for which BWE thresholds have previously been developed. Component C2 is believed to represent microbially derived organic matter, whereas C3 is believed to represent

Fig. 2. Sampling sites in (A) Port Curtis during the winter and fall surveys, (B) Port Botany during fall and (C) Port Phillip Bay during the fall and winter surveys 
degraded plant matter (Murphy et al. 2008b). Although 6 other natural fluorescent components have been identified in ballast water, they have not proved as reliable for tracking ballast water sources (Murphy et al. 2006).

One source of measurement error for CDOM is the inner filter effect, where reabsorption of emitted and/ or incident radiation by concentrated samples causes a reduction in measured light per molecule in solution. In another study in this region (Murphy et al. 2009a), inner filter effects were found to be insignificant (below 5\%) for $\mathrm{C} 2{ }^{*}$ below approximately $17 \mathrm{ppb}$ QSE. Samples from this study were relatively dilute with C2* intensities below 15.5 QSE at all but the freshwater end-member sites distant from the ports. Thus inner filter effects may have resulted in underestimation of intensities at these end-member sites, but would not have had a significant effect upon determined concentrations at sites within the ports.

Across the entire study, 271 CDOM samples and 243 trace element samples were analysed. Analysis occurred within 6 wk of sample collection for CDOM and within $8 \mathrm{mo}$ of sample collection for trace elements. Previous studies in both laboratories have found no significant impacts on data quality due to storing samples for this length of time.

Data quality control and statistical analysis. In general, the coefficients of variation ( $\mathrm{CV}=\mathrm{SD} / \mathrm{mean}$ ) for replicate samples collected from each site were small ( 2 to $8 \%$ ), indicating that measurements were precise despite limited replication. A small proportion of samples $(2.9 \%)$ were identified as severe outliers relative to 2 other replicates and were omitted from the dataset. An additional $2.6 \%$ of samples produced inconsistent data (i.e. showed higher or lower levels relative to their replicates) for 2 or fewer elements, usually Mn and P. For these samples, data for the inconsistent elements were removed, but data for the remaining elements were retained.

Analysis of variance (ANOVA) was used to test differences in tracer distribution between ports and be- tween seasons. To test spatial differences, data from surveys conducted in fall only (Table 2) were compared, to limit confounding due to temporal variability. To test temporal differences, only surveys from Port Phillip Bay and Port Curtis were used, as these locations were sampled in 2 different seasons (Table 2). In all cases, data were (natural) log transformed to meet the criterion for homogeneity of variances before ANOVA was performed (SPPS version 15.0). However, differences in variability of tracers (even when river samples were excluded from the analysis), meant that ANOVA could not be used to evaluate port differences for $\mathrm{C}^{*}$ or $\mathrm{Ba}$, or to evaluate differences between seasons for Ba. For these comparisons, a non-parametric Kruskal-Wallis test was used.

Assessment of tracers for development of BWE thresholds. Tracer concentrations in ports were compared to those in the adjacent Tasman Sea to see what resolution they offered for discriminating coastal water and how consistent this was spatially and temporally. Considering all the port data (but excluding freshwater end-members), a theoretical mixing line was calculated between the maximum observed port tracer concentration and the Tasman Sea background (Fig. 1). The tracer concentration at $5 \%$ port water and $95 \%$ ocean water was then proposed as a conservative BWE threshold. The appropriateness of this threshold was then assessed for different sites within ports, with results expressed as the BWE efficiency at which the ballast tracer concentration would be within $2 \mathrm{SD}$ of the mean Tasman Sea concentration. This provided a measure of the probability of a false negative determination, i.e. the failure to detect a non-complying ballast tank. The probability of a false positive determination, i.e. incorrectly assessing a tank as being non-compliant, was also determined by calculating the port tracer concentration that would be indistinguishable from the ocean baseline (i.e. less than 2 SD above the mean) if only $5 \%$ of port water were retained in a ballast tank.

Table 2. Tracer concentrations found in ports during different seasons. Data are means \pm SD or measured range, and are in units of quinine sulphate equivalents (QSE) for $\mathrm{C}^{*}$ and $\mathrm{C}^{*}$ (chromophoric dissolved organic matter, $\mathrm{CDOM}$ ), $\mu \mathrm{g} \mathrm{l^{-1 }}$ for Ba, Mn and P (trace elements) and psu for salinity. Background tracer levels in the Tasman Sea were derived from Murphy et al. (2009a) (except salinity, which was from Murphy et al. 2007)

\begin{tabular}{|c|c|c|c|c|c|c|c|c|}
\hline & Date & $\mathrm{n}$ & $\mathrm{C} 2^{*}$ & $\mathrm{C} 3^{*}$ & Mn & $\mathrm{Ba}$ & $\mathrm{P}$ & Salinity \\
\hline Tasman Sea & & & $0.57 \pm 0.15$ & $0.35 \pm 0.08$ & $0.5 \pm 0.29$ & $4.85 \pm 0.78$ & $12.1 \pm 3.0$ & 34.3 to 37.8 \\
\hline Port Botany fall & 18 April 2007 & 24 & $3.8 \pm 3.6$ & $2.3 \pm 2.1$ & $1.7 \pm 1.5$ & $6.8 \pm 2.7$ & $17 \pm 4.2$ & $37.3 \pm 1.9$ \\
\hline Port Curtis winter & 21 August 2007 & 9 & $4.9 \pm 0.5$ & $2.3 \pm 0.2$ & $1.9 \pm 1.2$ & $7.0 \pm 0.4$ & $6.8 \pm 1$ & $35.8 \pm 0.1$ \\
\hline Port Curtis fall & 03 April 2008 & 17 & $8.1 \pm 2.9$ & $4.2 \pm 1.3$ & $1.9 \pm 1.6$ & $9.0 \pm 1.8$ & $6.9 \pm 1.3$ & $32.8 \pm 0.7$ \\
\hline Port Phillip fall & 24 April 2007 & 25 & $4.5 \pm 1.3$ & $2.3 \pm 0.7$ & $5.2 \pm 2.4$ & $9.8 \pm 1$ & $81.2 \pm 15.9$ & $41.2 \pm 0.7$ \\
\hline Port Phillip spring & 25 October 2007 & 25 & $4.7 \pm 1.4$ & $2.4 \pm 0.7$ & $3.4 \pm 1.4$ & $9.3 \pm 1.6$ & $63.8 \pm 16.9$ & $37.5 \pm 0.8$ \\
\hline
\end{tabular}




\section{RESULTS}

\section{Physico-chemical parameters and conservative tracers}

Vertical profiles of physico-chemical parameters confirmed that the water column at most sites was relatively mixed in the upper $5 \mathrm{~m}$ and that our samples were representative of the surface layer. Salinity within all ports was $\geq 32 \mathrm{psu}$, with sites closest to port/ bay entrances generally having the highest salinities and those closest to freshwater inputs having the lowest (Fig. 3). Salinity at Port Botany showed the largest range (between 32 and $38.5 \mathrm{psu}$ ), but in other surveys, the total salinity range was small, only about 3 psu, excluding freshwater end-members. Despite difficulties with the salinity probes during the Port Botany and first Port Curtis surveys (which consistently over-estimated actual salinities by up to 2 psu), the results show that background salinities in Port Curtis varied seasonally, with lower salinities in autumn compared to winter, reflecting the region's summer-dominated rainfall $(F=56.6, \mathrm{p}<0.001)$. Salinity was also different seasonally in Port Phillip Bay, but with higher salinities in fall compared to spring ( $F=2.542, \mathrm{p}=0.05$, respectively).
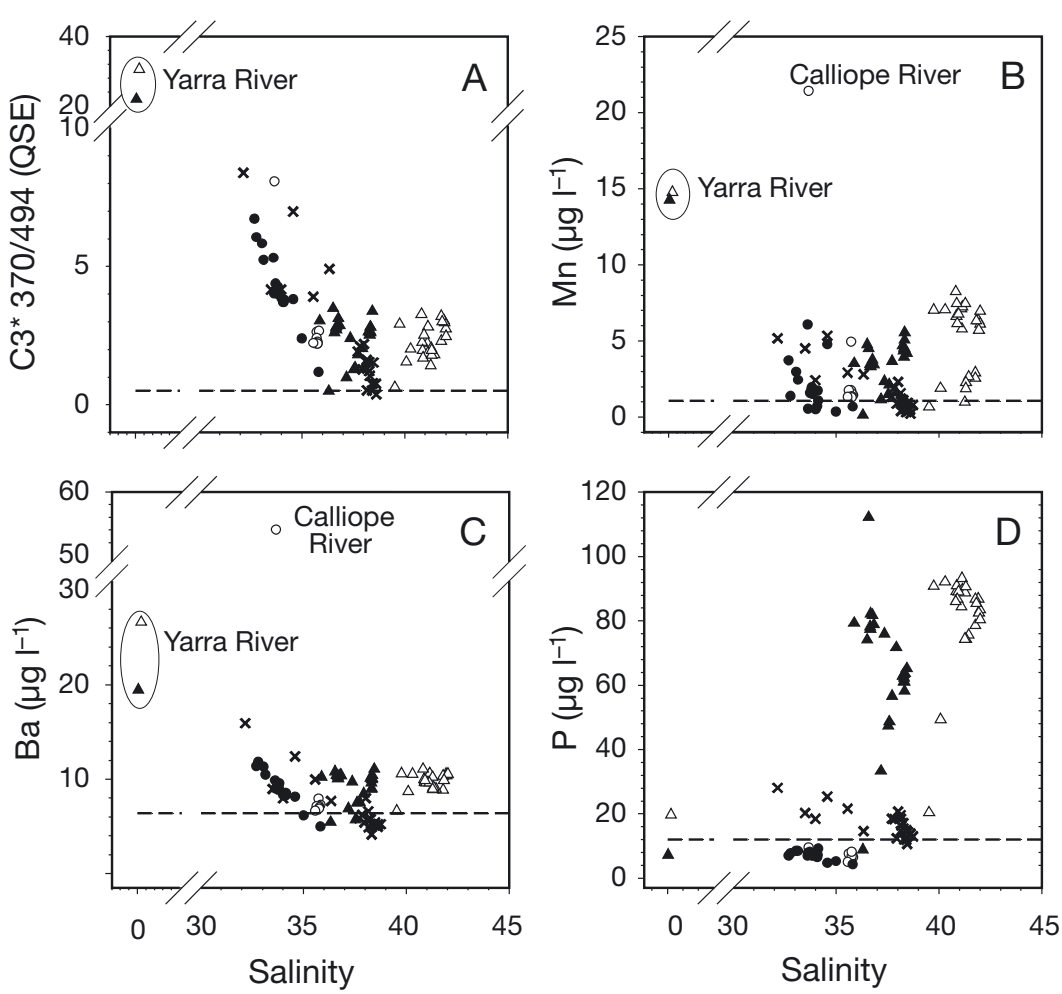

Fig. 3. Salinity and (A) C3* chromophoric dissolved organic matter (CDOM), (B) manganese, (C) barium and (D) phosphorus distribution within and between ports. Data are means at average depth sampled. The dashed line represents the upper 95th percentile of tracers in the Tasman Sea (Murphy et al. 2007, 2009a), providing a benchmark for comparison. Symbols: $x=$ Port Botany fall $; \circ=$ Port Curtis winter $; \bullet=$ Port Curtis fall $; \quad=$ Port Phillip Bay spring; $\boldsymbol{\Lambda}=$ Port Phillip Bay fall
The conservative trace element Mo (Palmer \& Edmond 1993, Sohrin et al. 1998) was less variable than salinity (data not shown), with low concentrations for both tracers coinciding in freshwater. Mo only showed significant seasonal differences between surveys in Port Phillip Bay with average $( \pm \mathrm{SD})$ values in April 2007 being $\sim 15 \%$ higher than in October 2007 $\left(11.9 \pm 0.4 \mu \mathrm{g} \mathrm{l}^{-1}\right.$ compared to $9.9 \pm 0.8 \mu \mathrm{g} \mathrm{l}^{-1} ; F=9.256$, $\mathrm{p}=0.004)$. Overall, Mo and salinity were weakly correlated ( $\mathrm{n}=100 ; \mathrm{R}^{2}=0.652$ ), and because Mo showed no greater resolution than salinity, it was excluded from further analysis.

\section{CDOM}

CDOM C2* (320/414 nm) ranged from 0.63 to 52.31 QSE and was highly correlated with C3* (370/ $494 \mathrm{~nm}$ ) across the entire range of measurements ( $\mathrm{n}=$ $\left.99, \mathrm{r}^{2}=0.99, \mathrm{p}=<0.001\right)$. Due to near-perfect correlation between $\mathrm{C} 2{ }^{*}$ and $\mathrm{C} 3{ }^{*}$ and because $\mathrm{C} 3{ }^{*}$ appears to be derived from exclusively terrestrial material (Murphy et al. 2008b), only data for C $3^{*}$ are presented. However, $\mathrm{C} 2{ }^{*}$ intensities can be estimated by multiplying $\mathrm{C}^{*}$ by 1.68 and adding 0.55 , except for sites with low $\mathrm{C} 2{ }^{*}$ concentrations such as Port Botany and at the entrance to Port Phillip Bay, where C2* is better estimated by $1.68 \times\left(\mathrm{C} 3^{*}\right)$.

CDOM showed larger gradients between sites compared to salinity, with C3* concentrations ranging between 0.38 and 8.38 QSE, excluding freshwater end-members (Fig. 3A). As expected, CDOM concentrations were lowest at sites close to port entrances and increased at sites adjacent to freshwater inputs, but were similar across Port Botany and Port Phillip Bay as well as 1 Port Curtis survey (Table 2). Interestingly, CDOM concentrations showed little seasonality in Port Phillip Bay, whereas in Port Curtis, there were lower concentrations in winter compared to fall (significant port $\times$ season interaction; $\mathrm{n}=73, F=8.77, \mathrm{p}<0.01$ ).

\section{Trace elements}

The air blanks showed very low concentrations $\left(\mathrm{gg} \mathrm{l}^{-1}\right)$ of all trace elements: Mo 0.12; Ba 0.03; Mn 0.003; $P$ 0.08) indicating minimal baseline concentrations. 
Manganese

Average $\mathrm{Mn}$ concentrations were similar in Port Botany and Port Curtis $\left(\sim 1.8 \mu \mathrm{g} \mathrm{l}^{-1}\right)$ but were at least $50 \%$ higher in Port Phillip Bay ( $=66, F=19.27, \mathrm{p}<$ 0.001). Like CDOM, concentrations were lowest at port entrances and highest close to freshwater inputs, with a significant outlier at 1 upstream site in the Calliope

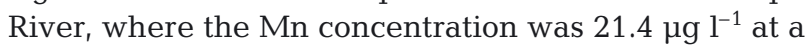
salinity of $33 \mathrm{psu}$. Of the total Mn samples, $79 \%$ exceeded the upper 95th percentile (mean $+2 \mathrm{SD}$ ) of Mn concentrations in the Tasman Sea. Interestingly, Mn concentrations showed significant seasonality in the 2 Port Phillip Bay surveys, but not in Port Curtis (Table 2). However, when the Yarra River freshwater end-members and Calliope River outlier were excluded from the ANOVA, there was no difference in Mn between ports or seasons and no significant interaction term.

\section{Barium}

Ba concentrations averaged between 6.8 and $9.8 \mu \mathrm{g}$ $\mathrm{l}^{-1}$ (Table 2) but were as high as $15.9 \mu \mathrm{g} \mathrm{l}^{-1}$ upstream from Port Botany in the Georges River estuary, and up to $53.9 \mathrm{\mu g} \mathrm{l}^{-1}$ at the upstream site in the Calliope River draining into Port Curtis (Fig. 3C). Unequal variances between ports precluded the use of ANOVA to assess spatial and seasonal variation, but non-parametric tests revealed significant between-port differences in Ba concentration. Overall, there was evidence of some seasonality in $\mathrm{Ba}$ at Port Curtis, with concentrations remaining fairly stable in Port Phillip Bay (Table 2). Similar to $\mathrm{Mn}, 80 \%$ of samples had higher Ba concentrations than the upper 95th percentile of Mn concentrations in the Tasman Sea (Fig. 3C).

\section{Phosphorus}

Concentrations of the element $\mathrm{P}$ were significantly different between ports ( $\mathrm{n}=65, F=460$, $\mathrm{p}<0.001$ ), with $\mathrm{P}$ in Port Phillip Bay approximately an order of magnitude higher than in Port Curtis (Table 2), even at sites close to the port entrance. Port Botany had intermediate P concentrations (Fig. 3D). ANOVA indicated no difference between seasons in both Port Phillip Bay and Port Curtis. P was within the upper 95th percentile of the ocean background concentration at Port Curtis and at a few sites close to the entrance of Port Botany as well as freshwater end-members connected to Port Phillip Bay. Otherwise, $\mathrm{P}$ concentrations in port were well above Tasman Sea concentrations.

Overall, CVs for replicate samples from each port survey ranged from 1.9 to $13.6 \%$. The CV indicates precision of the sampling + analytical process, so is increased by natural variability in tracer concentrations at sites, sample contamination, analytical error or any combination of these factors. Control samples (blanks) to assess sample contamination all had very low trace concentrations, and our quality assurance/quality control process confirmed consistency between replicates, so the likely source of variation contributing to high CVs was actual variability in tracer concentrations within sites. Considering the entire dataset, CVs were greatest for CDOM and P during the Port Botany fall and Port Phillip fall surveys (approximately $8 \%$ and $12 \%$, respectively), probably due to outward sediment fluxes of dissolved organic matter and P during sampling at shallow sites.

\section{Assessment of tracers for development of BWE thresholds}

In almost all cases, coastal tracers in ports exceeded the upper 95th percentile of adjacent Tasman Sea concentrations (Fig. 3). CDOM had the greatest discriminatory power, with $99 \%$ of sites sampled having higher C3* concentrations than the Tasman Sea, compared to Mn (79\%), Ba (80\%) and P (58\%). Given this relatively high degree of separation between port and ocean tracer concentrations for $\mathrm{C} 3^{*}, \mathrm{Mn}$, and $\mathrm{Ba}, \mathrm{BWE}$ thresholds were developed and are presented for each tracer (Fig. 4). In developing thresholds, there were 2 considerations acting in opposite directions to elevate or reduce thresholds, respectively: minimising the potential for false positive determinations and being able to detect water derived from low-tracer ports.

A conservative ballast water threshold for C3* was therefore determined using the maximum concentration of C3* measured within ports (8.38 QSE at a riverine site in Port Botany), and the upper 95th percentile value of 0.51 QSE in the Tasman Sea (Table 2; Murphy et al. 2009a). The C3* threshold of 0.90 QSE was calculated as $(0.05 \times 8.38)+(0.95 \times 0.51)($ i.e. $95 \%$ replacement of port water with ocean water), and its utility for diagnosing BWE of ballast water from the 3 ports is depicted in Fig. 4A. Ranges of $\mathrm{C} 3{ }^{*}$ concentrations measured within ports (Fig. 4, right hand side) and directly at shipping berths (Fig. 4, left hand side) are shown to diminish when mixed with Tasman Sea water, and the BWE efficiency needed to reduce port concentrations in ballast tanks to below threshold (i.e. compliant) levels is summarised in Table 3. For ballast water from berths in Port Curtis, BWE efficiencies of $78 \%$ (winter low) to $90 \%$ (fall high) would be required. Similarly, for ballast water from berths in Port Phillip Bay, maximum BWE efficiencies of $\sim 81 \%$ (spring) and $78 \%$ (fall) would be required. While the conservative threshold holds reasonably well for bal- 

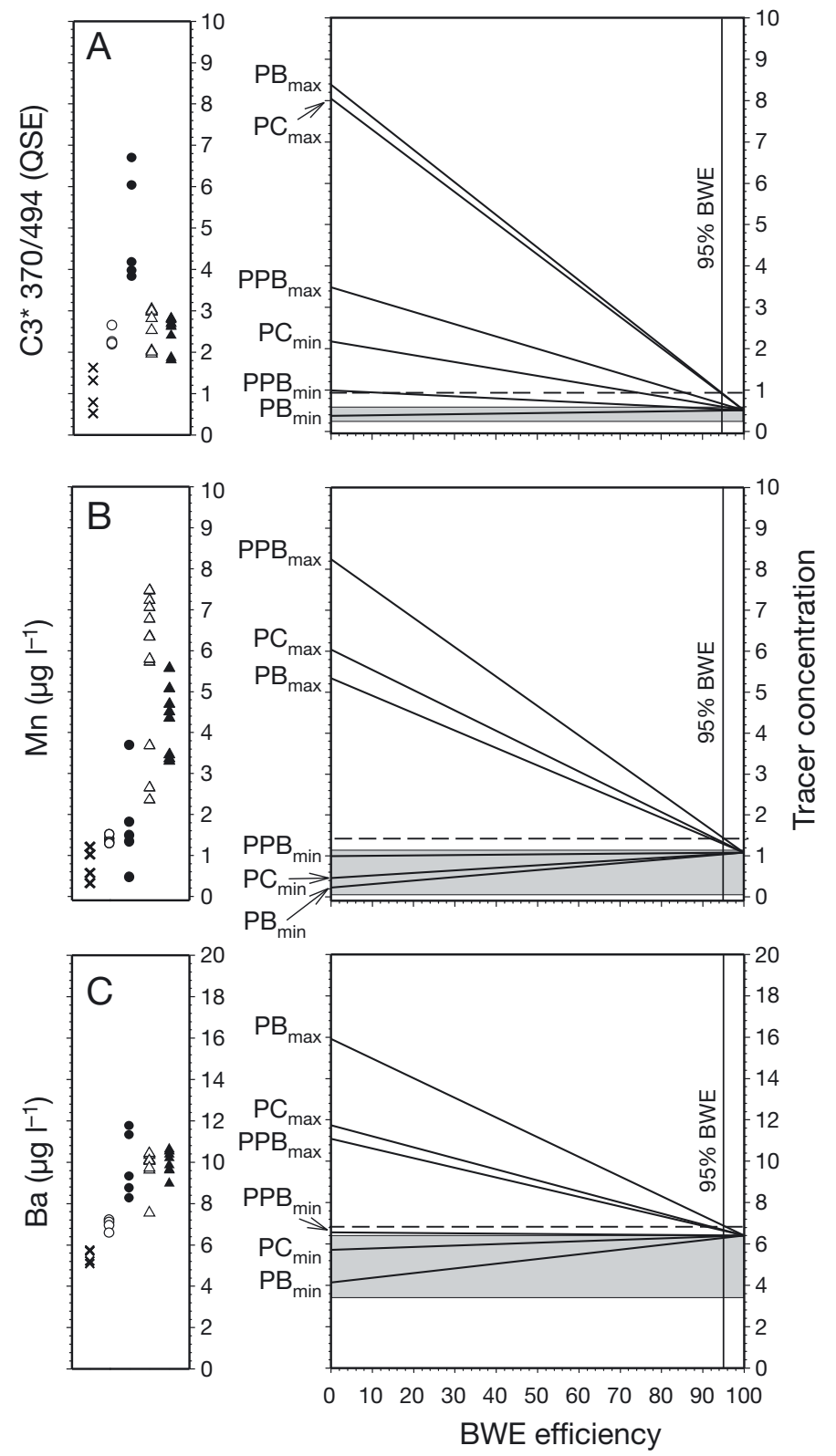

Fig. 4. (A) $\mathrm{C}^{*}$ chromophoric dissolved organic matter $(\mathrm{CDOM}),(\mathrm{B})$ manganese and $(\mathrm{C})$ barium tracer ranges in each port (excluding freshwater end-members) and how their concentration would decrease with ballast water exchange (BWE). The dashed horizontal line (BWE threshold) is the concentration of the tracer which would be achieved if port water containing the maximum tracer concentration was volumetrically replaced with ocean water at $95 \%$ BWE efficiency. Grey band: tracer concentration (mean $\pm 2 \mathrm{SD}$ ) in the ocean water adjacent to the source port water (in this case, the Tasman Sea; Murphy et al. 2009a). Left hand plots: tracer concentrations measured directly at shipping berths, as compared to the full range of tracer concentrations in each port (right hand plots). $\mathrm{PB}_{\max }$ and $\mathrm{PB}_{\min }$ are the maximum and minimum tracer values in Port Botany; PC: Port Curtis, PPB: Port Phillip Bay. Symbols: $x=$ Port Botany fall; $O=$ Port Curtis winter $; \bullet=$ Port Curtis fall; $\Delta=$ Port Phillip Bay spring; $\boldsymbol{\Delta}=$ Port Phillip Bay fall last water originating at berths in Port Phillip Bay and Port Curtis, it is less successful at determining BWE status of ballast water loaded in Port Botany. At the least coloured of the 4 berths sampled, C3 ${ }^{*}$ was 0.52 QSE and hence already below the threshold, while ballast from the most highly coloured berth would require only $65 \%$ replacement with oceanic seawater (Table 3). The threshold would also be less successful in determining the BWE status of ballast sourced from a number of nonberth sites in each of the ports, particularly those located close to the port entrance $\left(\mathrm{PC}_{\min }, \mathrm{PB}_{\min }\right.$ and $\left.\mathrm{PPB}_{\min }\right)$, with these sites at worst indistinguishable from the open ocean $\left(\mathrm{PC}_{\min }\right)$ or requiring significantly less than $95 \%$ exchange to bring them into compliance $\left(49 \%\right.$ for $\mathrm{PP}_{\min }$ and $38 \%$ for $\mathrm{PC}_{\min }$ ).

A Mn threshold of $1.4 \mu \mathrm{g} \mathrm{l}^{-1}$ was determined using the maximum concentration of $\mathrm{Mn}$ measured within ports (8.25 $\mathrm{gg}^{-1}$ in Port Phillip Bay), and the upper 95th percentile value of $1.08 \mu \mathrm{g} \mathrm{l}^{-1}$ in the Tasman Sea $([0.05 \times 8.25]+[0.95 \times 8.25] ;$ Table 2 ; Murphy et al. 2009a). Its utility for diagnosing BWE of ballast water from the 3 ports is shown in Fig. 4B. This threshold was moderately successful in determining the BWE status of ballast sourced from sites within Port Phillip Bay (but not the entrance; $\mathrm{PP}_{\mathrm{min}}$ ), with water from berths requiring 72 to $92 \%$ BWE in spring and 77 to $94 \%$ in fall (Table 3). In contrast, water from Port Botany and Port Curtis, including sites at berths, in shipping channels and the wider port area, required far less exchange to bring Mn concentrations below the threshold. Generally low Mn concentrations in Port Botany meant that water from berths required no exchange to be compliant. In Port Curtis, water from berths required 0 to $16 \%$ BWE in winter and 0 to $86 \%$ BWE in fall, but across the entire location, average BWE requirements were $\sim 32 \%$ in both seasons.

The Ba threshold of $6.9 \mu \mathrm{g}^{-1}$ (Fig. 4) was calculated using the maximum concentration of $\mathrm{Ba}$ measured within ports (15.9 $\mathrm{Mg} \mathrm{l}^{-1}$ in the Georges River estuary, Port Botany), and the upper 95th percentile value of $6.41 \mathrm{\mu g} \mathrm{l}^{-1}$ in the Tasman Sea $([0.05 \times 15.9]+[0.95 \times$ 6.41]; Table 2; Murphy et al. 2009a). Similar to Mn, Ba showed smaller differentials between port and ocean concentrations compared to CDOM, leading to 17 of 24 sites $(71 \%)$ in Port Botany and 6 of 9 sites $(67 \%)$ in the Port Curtis winter survey having Ba concentrations below the calculated threshold. As a result, water sourced from these ports would be challenging to track using $\mathrm{Ba}$. The threshold had greatest utility in Port Phillip Bay, where water from berths would require 81 to $88 \%$ (fall) or 57 to $88 \%$ (spring) BWE to bring ballast into compliance. In contrast, there was strong seasonality in BWE compliance for ballast water sourced from Port Curtis, requiring BWE efficiencies of 73 to $91 \%$ in fall, but only 0 to $37 \%$ in winter (Table 3 ). 


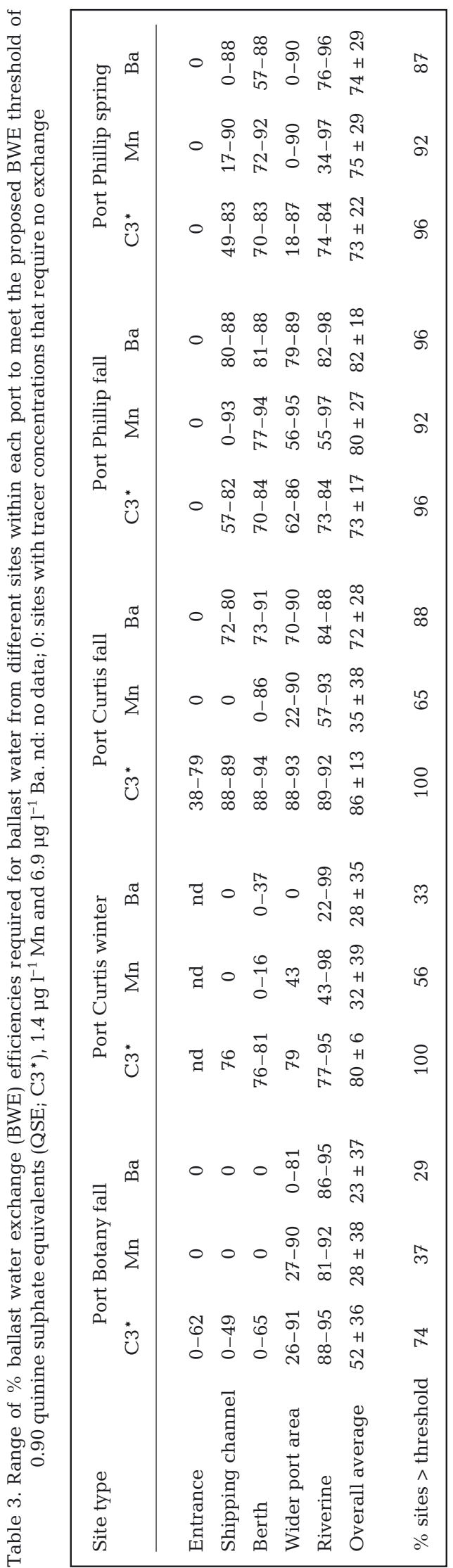

\section{DISCUSSION}

While there has been steady progress in identifying and quantifying the distribution of chemical tracers suitable for verifying BWE (see Murphy et al. 2004, 2006, 2008a, 2009a), until now a consistent and intuitive framework for developing tracer thresholds to assess BWE compliance has been lacking. This study proposes and tests such a framework, using data from 3 ports in Australia representative of a range of conditions that could be encountered in unexchanged ballast tanks. Australian ports typically have very high salinities (Table 1), which normally correlate with low $\mathrm{CDOM}$ and relatively low dissolved trace element concentrations (Ferrari \& Dowell 1998, Blough \& Del Vecchio 2002, Hatje et al. 2003) that may be relatively difficult to distinguish from high salinity, low-tracer oceanic samples. For this reason, Australian ports represent especially challenging and informative test cases for developing and testing BWE verification thresholds.

\section{Ballast water tracer thresholds}

In developing BWE thresholds, the probability of 2 possible erroneous determinations needs to be considered: the false positive (i.e. the initial tracer concentration in ballast is too high to achieve a final concentration below the threshold even when diluted with $95 \%$ ocean water) and the false negative (i.e. the tracer concentration in ballast is below the threshold even when diluted with less than $95 \%$ of oceanic seawater). Fig. 1 depicts the trade-off between setting thresholds high enough to minimise the potential for false positive determinations, and retaining enough sensitivity to detect unexchanged ballast water derived from lowtracer ports. In this study, to minimise the rate of false positive determinations (i.e. reduce the likelihood of imposing a penalty when $95 \%$ BWE was carried out), the threshold was calculated using the maximum tracer concentrations observed both in ports and in the adjacent open ocean. This came at the cost of detection sensitivity, particularly for water sourced from Port Botany, which was located in a relatively open embayment.

The threshold proposed for CDOM $\left(\mathrm{C} 3^{*}\right)$ was considerably more robust than those for the trace elements $\mathrm{Mn}$ and $\mathrm{Ba}$. Larger differentials for $\mathrm{C}^{*}$ between port concentrations and the Tasman Sea (with $\geq 74 \%$ sites across all ports requiring exchange to be compliant) resulted in relatively high BWE requirements which were more consistent across seasons, particularly in Port Phillip Bay (Table 3). In general, water sourced from port entrances required the least exchange 
( 0 to $79 \%$ ), followed by water from the shipping channel $(0$ to $89 \%)$, at berths $(0-94 \%)$, the wider port area (18 to $93 \%$ ) and riverine sites (73 to $95 \%$ ). Water sourced from Port Curtis in fall had the highest BWE requirement $(86 \pm 13 \%)$, whereas water from Port Botany had the lowest (52 $\pm 36 \%$; Table 3 ).

In comparison, thresholds for $\mathrm{Mn}$ and Ba offered less utility for discriminating between coastal and oceanic seawater samples. Trace element concentrations in Port Botany and Port Curtis were both closer to ocean concentrations (yielding lower resolution to track coastal water) and more seasonally variable, leading to greater seasonality in the degree of BWE required to reach oceanic tracer levels. Water sourced from Port Curtis required $72 \pm 28 \%$ exchange in fall but only $28 \pm 35 \%$ in winter. No threshold could be established for $\mathrm{P}$ concentrations that would apply for all ports; however, $\mathrm{P}$ in samples from Port Phillip Bay always exceeded $20 \mathrm{\mu g} \mathrm{l}^{-1}$ and hence significantly exceeded background concentrations in the Tasman Sea of $12.1 \mathrm{\mu g}^{-1}$ (Table 2; Murphy et al. 2009a).

Table 4 shows how the thresholds calculated for these eastern Australian ports compare to those previously identified to discriminate ballast water exchanged in the northern Pacific and Atlantic Oceans and the Tasman Sea. Ba thresholds are most consistent across regions $\left(6.9-7.0 \mu \mathrm{g} \mathrm{l}^{-1}\right)$, followed by C3* $(0.7-$ 1.0 QSE), whereas Mn thresholds varied 2-fold (1.0$2.4 \mu \mathrm{g} \mathrm{l}^{-1}$ ). For $\mathrm{C}^{*}$ and $\mathrm{Ba}$, the thresholds developed in this study are comparable to, or marginally lower than, those identified by Murphy et al. (2009a) to separate exchanged and unexchanged ballast water sourced from south-eastern Australia. This is consistent with the observation that tracer concentrations in ballast tanks are often slightly elevated in ballast tanks relative to the ocean where ballasting occurred (Murphy et al. 2008a), a result that may be attributable to a combination of factors including the prevalence of relatively low BWE efficiencies among the existing shipping fleet.

The potential for identifying coastal ballast water from eastern Australian ports depends on the relevant threshold concentration. Using the CDOM C3* Pacific/ Atlantic threshold (0.7 QSE), 96\% of port sites would be identified as coastal compared to $92 \%$ of sites using this study's threshold (0.9 QSE) and $91 \%$ of sites using the Tasman Sea threshold (1.0 QSE). For Mn, the proportion of sites verifiable as coastal ballast increases from $49 \%$ to $56 \%$ to $81 \%$ as the threshold level decreases from 2.6 to 2.0 to $1.0 \mu \mathrm{g} \mathrm{l}^{-1}$ using the Tasman Sea, Atlantic, and Pacific thresholds, respectively. Decreasing the threshold therefore increases the sensitivity of detecting coastal water but also increases the probability that ballast from some ports would need more than $95 \%$ replacement with oceanic seawater in order to become compliant. In such situations, how-
Table 4. Potential univariate threshold levels for ballast water exchange (BWE) verification using $\mathrm{C} 2{ }^{*}$ and $\mathrm{C} 3^{*}$ chromophoric dissolved organic matter (CDOM, in units of quinine sulphate equivalents, QSE) and barium $(\mathrm{Ba})$ and manganese $(\mathrm{Mn})\left(\mu \mathrm{g} \mathrm{l}^{-1}\right)$ identified in this and previous studies. Ballast water with values above these thresholds retains significant coastal influences

\begin{tabular}{|lcccc|}
\hline & $\mathrm{C} 2^{*}$ & $\mathrm{C} 3^{*}$ & $\mathrm{Ba}$ & $\mathrm{Mn}$ \\
\hline Pacific & $1.7^{\mathrm{b}}$ & $0.7^{\mathrm{b}}$ & & $1^{\mathrm{c}}$ \\
Atlantic & & & $7^{\mathrm{a}, \mathrm{c}}$ & $2^{\mathrm{c}}$ \\
Tasman Sea & $1.8^{\mathrm{d}}$ & $1.1^{\mathrm{d}}$ & $6.8^{\mathrm{d}}$ & $2.6^{\mathrm{d}}$ \\
This study & 1.6 & 0.9 & 6.9 & 1.4 \\
aData from Murphy et al. $(2004),{ }^{\mathrm{b}}(2006),{ }^{\mathrm{c}}(2008 \mathrm{a}),{ }^{\mathrm{d}}(2009 \mathrm{a})$ \\
\hline
\end{tabular}

ever, ports with high tracer concentrations are likely to also have lower salinity (Fig. 3; Ferrari \& Dowell 1998, Blough \& Del Vecchio 2002), such that salinity itself could be used to verify coastal ballast origin.

\section{Utility of tracers in BWE verification}

Published data on Ba and Mn concentrations in ports from the Southern Hemisphere are limited, and existing data for CDOM are almost exclusively measured by absorbance rather than fluorescence emission (Clementson et al. 2004), while P is typically measured as filterable reactive $\mathrm{P}$, not total dissolved $\mathrm{P}$. This study of coastal tracers in south-eastern Australian ports therefore adds to the global database and provides regulators with an evidence-based approach for BWE verification.

Spatial and seasonal variability in ports is a practical complication in the use of chemical tracers for verifying BWE. Ports experiencing greater exchange with coastal waters and lower freshwater inflows would be expected to have lower tracer concentrations, making them potentially more difficult to verify as ballast water sources. Significant variability in tracer concentrations would arise from episodic or seasonal freshwater inflows and long water residence times that allow tracers to accumulate. Port Botany, due to a combination of the port size as well as relatively strong signals emanating from the nearby Georges River estuary, showed steep gradients in CDOM concentrations, whereas tracer signals throughout Port Phillip Bay were relatively stable (Fig. 3A). The long water residence time in the bay ( 1 yr; Harris et al. 1996) and relatively restricted harbour entrance is likely an important determinant of tracer variability, and is in marked contrast to more rapid flushing rates in the relatively open waters of Port Botany and Port Curtis. Overall, the data collected in eastern Australian ports showed overlapping tracer concentrations between ports and 
seasons (Fig. 3), indicating good spatial and temporal stability for use in characterising ballast sources.

CDOM stood out as the best performing tracer in this study because it demonstrated the steepest concentration gradients from ports to the adjacent ocean. The trace elements $\mathrm{Mn}, \mathrm{Ba}$ and $\mathrm{P}$ provided little, or inconsistent, additional resolution for identifying coastal ballast. Despite this, we caution against the use of a single criterion to verify BWE. Instead, we recommend a tiered approach, where one would test ballast water for salinity $<30 \mathrm{psu}$, indicating an unambiguous coastal source; then test for CDOM that exceeds the range of ocean values derived from the geographic region of interest. Evidence of non-compliance resulting from tracer testing should then be interpreted in light of the ship's record of ballast water origin and management. Tests for the trace elements $\mathrm{Mn}$, Ba or $\mathrm{P}$ would be reserved for situations in which further evidence of non-compliance is considered a high priority, for example, if the ballast water is suspected to have been sourced from a high-risk ballast source such as Port Phillip Bay (i.e. test for P; Hewitt et al. 2004).

\section{Future research}

Although this study has contributed significantly to the global database, further data on CDOM variability in the world's ports and along oceanic shipping routes are needed for accurate prediction of the origin of water in ships' ballast tanks, and to define thresholds that strike the appropriate balance between sensitivity for detecting unexchanged ballast and robustness to natural variability in port and ocean concentrations. Advances in technology (e.g. optical instrumentation) and remote sensing are likely to increase the feasibility of generating large databases for this purpose. Similarly, technologies and decision support systems that increase the opportunity for real-time verification of BWE compliance are a high priority for future research, including the development and testing of sturdy and affordable in situ instruments that can be lowered into ballast tanks. CDOM was the most sensitive tracer of water origin in this study, and along with $\mathrm{P}$ is the most amenable to in situ measurement.

\section{CONCLUSIONS}

BWE by ships will continue until at least 2016 during the phasing-in of treatment technology (IMO 2004), and assessments of whether ships have conducted BWE are likely to be undertaken for at least the next $7 \mathrm{yr}$. Surveys of CDOM and trace element ( $\mathrm{Ba}, \mathrm{P}, \mathrm{Mn}$ ) concentrations in 3 saline ports in eastern Australia indicated that these tracers were in most cases significantly elevated above background ocean levels. CDOM was a particularly sensitive tracer of Australian port waters, usually providing far greater sensitivity for discriminating potential ballast water sources than salinity or the trace elements. This supports previous research suggesting that it would be possible to verify BWE by measuring concentrations of naturally occurring chemical tracers in ballast tanks. This study has further provided a framework for defining accurate concentration thresholds that delineate between exchanged and unexchanged ballast water. Thresholds must be applicable over large geographic regions and should be robust to spatial and temporal variability of tracer concentrations within and between ports. Based upon the highest concentrations observed in Australian ports and baseline levels offshore in the Tasman Sea, ballast tanks with tracer concentrations exceeding 1.6 QSE at $\lambda_{\text {ex }} / \lambda_{\text {em }}=320 / 414 \mathrm{~nm}\left(\mathrm{C} 2^{*}\right)$ or 0.9 QSE for CDOM at $\lambda_{\text {ex }} / \lambda_{\text {em }}=320 / 414 \mathrm{~nm}\left(\mathrm{C} 3^{*}\right)$ would be assumed to have been derived wholly from coastal environments, or else incompletely exchanged at sea. Similarly, tanks with Mn exceeding $1.4 \mu_{\mathrm{g}} \mathrm{l}^{-1}$ and Ba exceeding $6.9 \mu \mathrm{g} \mathrm{I}^{-1}$ would be assessed as non-compliant. While these thresholds are likely to discriminate most unexchanged ballast water from coastal ports, partially-exchanged ballast tanks from high-salinity/low tracer ports, or from locations near or external to port entrances, may be erroneously judged as compliant according to these criteria.

Acknowledgements. We sincerely thank P. Jones, R. Watson, N. Biggins, A. Davis, and J. Clark for assistance with field operations. We acknowledge P. Field of Rutgers Inorganic Analytical Laboratory, Rutgers University, for trace element analyses, and D. Sparks, G. Smith, A. Arnwine, T. Mullady, J. Boehme and R. Hartman of SERC for CDOM analyses. Technical support for the project was provided by SERC and by J. Iles at UTS. Thanks to M. Noble for preparing site maps, to L. Jones and N. Parker at Biosecurity New Zealand for administrative support and to H. Cribb, P. Fisher, T. Glasby, K. Hayes and A. Morton for help with sourcing port salinity data. This work was funded by Biosecurity New Zealand and is SIMS contribution no. 0037 .

\section{LITERATURE CITED}

Aquenal (2001) Exotic marine pests survey Port of Launceston, Tasmania. Final report prepared for Port of Launceston Pty Ltd, Hobart

Arthington AH, Pusey BJ (2003) Flow restoration and protection in Australian rivers. River Res Appl 19:377-395

Blough NV, Del Vecchio R (2002) Chromophoric DOM in the coastal environment. In: Hansell DA, Carlson CA (eds) Biogeochemistry of marine dissolved organic matter. Academic Press, San Diego, CA, p 509-546

> Burford MA, Alonghi DM, McKinnon AD, Trott LA (2008) Primary production and nutrients in a tropical macrotidal estuary, Darwin Harbour, Australia. Estuar Coast Shelf Sci 79:440-448

Carpenter PD, Butler ECV, Higgins HW, Mackey DJ, Nichols PD (1991) Chemistry of trace elements, humic substances 
and sedimentary organic matter in Macquarie Harbour, Tasmania. Aust J Mar Freshw Res 42:625-654

Clementson LA, Parslow JS, Turnbull AR, Bonham PI (2004) Properties of light absorption in a highly coloured estuarine system in south-east Australia which is prone to blooms of the toxic dinoflagellate Gymnodinium catenatum. Estuar Coast Shelf Sci 60:101-112

Coble PG, Schulz CA, Mopper K (1993) Fluorescence contouring analysis of DOC intercalibration experiment samples - a comparison of techniques. Mar Chem 41:173-178

CRIMP (Centre for Research on Introduced Marine Pests) (1996) Introduced species survey, Port of Devonport, Tasmania. CSIRO Division of Fisheries, Hobart, Australia

CSLC (California State Lands Commission) (2006) Ballast water regulations for vessels arriving at California ports or places after departing from ports or places within the Pacific Coast region. CSLC rule: Title 2, CCR Division 3, Chapter 1, Article 4.6 (effective March 22, 2006)

Davis JR, Koop K (2006) Eutrophication in Australian rivers, reservoirs and estuaries - a southern hemisphere perspective on the science and its implications. Hydrobiologia 559:23-76

Drake LA, Doblin MA, Dobbs FC (2007) Potential microbial bioinvasions via ships' ballast water, sediment, and biofilms. Mar Pollut Bull 55:333-341

EPA (Environmental Protection Agency) Victoria (2004) Waste management policy (ships' ballast water), Victoria government gazette No. S 100. The Craftsman Press Pty Ltd, Melbourne

Ferrari GM, Dowell MD (1998) CDOM absorption characteristics with relation to fluorescence and salinity in coastal areas of the southern Baltic Sea. Estuar Coast Shelf Sci 47: 91-105

Field MP, LaVigne M, Murphy KR, Ruiz GM, Sherrell RM (2007) Direct determination of P, V, Mn, As, Mo, Ba and U in seawater by SF-ICP-MS. J Anal At Spectrom 22: 1145-1151

Harris G, Batley G, Fox D, Hall D and others (1996) Port Phillip Bay environmental study final report. CSIRO, Canberra

Hatje V, Apte SC, Hales LT, Birch GF (2003) Dissolved trace metal distributions in Port Jackson estuary (Sydney Harbour), Australia. Mar Pollut Bull 46:719-730

Hayes KR, Barry SC (2008) Are there any consistent predictors of invasion success? Biol Invasions 10:483-506

Hayes KR, Sliwa C, Migus S, McEnnulty F, Dunstan P (2005) National priority pests-Part II. Ranking of Australian marine pests. Final report for the Australian Government Department of Environment and Heritage. CSIRO Division of Marine Research, Hobart

Hewitt CL, Campbell ML, Thresher RE, Martin RB and others (2004) Introduced and cryptogenic species in Port Phillip Bay, Victoria, Australia. Mar Biol 144:183-202

Hunt CD, Tanis D, Bruce E, Taylor M (2007) Optical signatures of seawater and potential use for verification of midocean ballast water exchange. Mar Ecol Prog Ser 331: $35-47$

IMO (International Maritime Organisation) (2004) International Convention for the Control and Management of Ships Ballast Water and Sediments. BWM/CONF/36, 16 February 2004. IMO, London

Kostoglidis A, Pattiaratchi CB, Hamilton DP (2005) CDOM and its contribution to the underwater light climate of a shallow, microtidal estuary in south-western Australia. Estuar Coast Shelf Sci 63:469-477

Lewis S, Hewitt C, Melzer A (2001) Port survey for introduced marine species - Port Curtis. Final report. Centre for Environmental Management, Centre for Land and Water
Resource Management, Central Queensland University, Gladstone

Longmore AR (2008) Port Phillip Bay environmental management plan: monitoring the state of bay nitrogen cycling (2006-2007). Marine and Freshwater Fisheries Research Institute, Queenscliff

MAF (Ministry of Agriculture and Forestry) (2005) Import health standard for ships' ballast water from all countries. Rule issued pursuant to Section 22 of the Biosecurity Act 1993 on 13 June 2005, New Zealand Ministry of Agriculture and Forestry, Wellington

MAF (Ministry of Agriculture and Forestry) (2007) Managing and controlling the risk to the marine environment from ballast water discharges: New Zealand's response to the international convention for the control and management of ship's ballast water and sediments. MAF Biosecurity New Zealand Discussion Paper No. 2007/04, New Zealand Ministry of Agriculture and Forestry, Wellington

> Murphy K, Boehme J, Coble P, Cullen J and others (2004) Verification of mid-ocean ballast water exchange using naturally occurring coastal tracers. Mar Pollut Bull 48: 711-730

Murphy KR, Ruiz GM, Dunsmuir WTM, Waite TD (2006) Optimized parameters for fluorescence-based verification of ballast water exchange by ships. Environ Sci Technol 40: 2357-2362

Murphy KR, Boehme JR, Ruiz GM (2007) Verification of midocean ballast water exchange by commercial ships arriving to New Zealand. Final report to the New Zealand Ministry of Agriculture and Forestry. Smithsonian Environmental Research Center, Edgewater, MD

> Murphy KR, Field MP, Waite TD, Ruiz GM (2008a) Trace elements in ships' ballast water as tracers of mid-ocean exchange. Sci Total Environ 393:11-26

> Murphy KR, Stedmon CA, Waite TD, Ruiz GM (2008b) Distinguishing between terrestrial and autochthonous organic matter sources in marine environments using fluorescence spectroscopy. Mar Chem 108:40-58

> Murphy KR, Boehme JR, Noble M, Smith G, Ruiz GM (2009a) Deducing ballast water sources in ships arriving to New Zealand from southeastern Australia. Mar Ecol Prog Ser 390:39-53

Murphy KR, Doblin MA, Boehme JR, Ruiz GM (2009b) Spatial and temporal variation in CDOM and trace elements in eastern Australian ports. MAF Biosecurity New Zealand Technical Paper No. 2009/45. New Zealand Ministry of Agriculture and Forestry, Wellington

Palmer MR, Edmond JM (1993) Uranium in river water. Geochim Cosmochim Acta 57:4947-4955

> Sohrin Y, Fujishima Y, Ueda K, Akiyama S, Mori K, Hasegawa H, Matsui M (1998) Dissolved niobium and tantalum in the North Pacific. Geophys Res Lett 25:999-1002

Taylor CM, Hastings A (2005) Allee effects in biological invasions. Ecol Lett 8:895-908

Underwood AJ, Keough MJ (2001) Supply-side ecology: the nature and consequences of variations in recruitment of intertidal organisms. In: Bertness MD, Gaines SD, Hay ME (eds) Marine community ecology. Sinauer Associates, Sunderland, MA, p 183-200

US Coast Guard (2004) Mandatory ballast water management program for US waters: final rule, 33 CFR 151, Subpart D. United States Coast Guard, Washington, DC

> Verling E, Ruiz GM, Smith DL, Galil B, Miller AW, Murphy KR (2005) Supply-side invasion ecology: characterizing propagule pressure in coastal ecosystems. Proc Biol Sci 272:1249-1256

Williamson M (1996) Biological invasions. Chapman \& Hall, London 